\title{
Cooperation and Conflict: Duality of the Sino-European Political Relations-A Perspective of Cultural Values
}

\author{
ZHANG Li-hua \\ Tsinghua University, Beijing, China
}

\begin{abstract}
Since the establishment of European Union (EU) on November 1, 1993, China has been developing its economic relations with EU at a rapid pace. The bilateral trade interdependency is enhanced correspondingly. However, the Sino-European political relations are of cooperative and conflicting nature all the time. The political attitude of EU toward China becomes even more active with more defensive mind as the Sino-European relations underwent four stages of evolution, namely, long-term relations, constructive partnership, mature partnership and competitive partnership. Chinese government has always held an attitude of proactively developing relations with the EU. In 1998, China established the "cooperative partnership" with EU. In 2001, the cooperative partnership was upgraded into "comprehensive partnership". In 2003, China advocated the establishment of the "comprehensive strategic partnership" with Europe and established "strategic partnership" with many member states of EU. Despite the smooth development in Sino-European relations, the political relations between China and EU saw conflicts and frictions from time to time. For instance, European Parliament issued resolutions against China from time to time. With regard to certain important international political issues, China has sharply different opinions with EU.
\end{abstract}

Keywords: the Sino-European, political relations, cooperation and conflict

\section{Duality of Sino-European Political Relations}

For the past two decades, the political relations between China and Europe were cooperative and confrontational at the same time. Such a reality indicates the duality of the Sino-European relations.

\section{Exchange and Cooperation Between China and EU}

\section{Strategic Partnership}

In 2003, China proposed to establish "the comprehensive strategic partnership" between China and EU and set up "strategic partnership" with many European countries. In 2013, China and EU jointly released "2020 China-EU Cooperation Strategic Plan”. In spring 2014, President XI Jin-ping paid a visit to the headquarters of EU. China and EU issued a joint statement for the first time and put forward to create "the four types of partnership of peace, growth, reform and civilization". In the meantime, President XI also defined the Sino-EU relations as "compound relationship with high interdependency" with an aim to combine the "two powers, two markets and two civilizations" of China and Europe (LI, 2014).

\section{Dialogue Mechanism}

In 1994, China and EU signed an agreement to set up their political dialogue mechanism. Both parties 
decided upon building the annual meeting mechanism, i.e. the EU-China summit. In 1997, China and EU reached an agreement that the human rights dialogue should be carried out biannually. By June 2014, China and EU had conducted human rights dialogues for over 30 times.

\section{Educational, Scientific and Cultural Cooperation}

From 1998 to 2008, China and EU carried out higher education cooperation programs twice. In 2011, "China-EU Year of Youth" series activities were launched. In 2012, "China-EU Cultural Dialogue Year" activities were jointly organized by the Ministry of Culture, People's Republic of China (PRC) and Education and Culture Department, European Commission. In the same year, China-UK High Level People-to-People Dialogue Forum and China-EU High Level People-to-People Dialogue Forum were initiated. In addition, China and many member countries of EU organized many "Culture Year" activities of various forms.

In 2004, China started to establish Confucius Institutes overseas. By the end of 2012, China built 134 Confucius Institutes and 112 Confucius lecture Halls in European countries, most of which were established in EU member countries. Besides this, China and EU had some cooperative projects in the fields including science and technology, energy and environment protection.

\section{Cooperation in the International Community}

China and EU have the same position in terms of opposing the nuclear arms race and promoting nuclear disarmament. Many member countries of EU and China have joined in the Nuclear Non-Proliferation Treaty and have been committed to promoting nuclear disarmament and nuclear non-proliferation via international organizations. With regard to the United Nations Climate conference and environment protection organizations, China and EU have wide room for close coordination and cooperation.

\section{Conflicts and Friction Between China and EU}

The dark side of Sino-EU political relations can be illustrated in the serious disagreements and conflicts between China and EU in terms of the following issues.

\section{Human Rights Issue}

During the period from 1993 to 1997, some member countries of EU such as Denmark, Germany, UK, the Netherland together with the United States presented the proposal of condemning China's human rights issue at the UN Human Rights Commission for consecutive seven years (WANG, 2009). EU Parliament had approved 13 resolutions on denouncing China's human rights issues from 1999 to 2010.

\section{Taiwan Issues}

From 1996 to 2005, European Parliament approved 14 Taiwan-related resolutions, most of which were against China's policies toward Taiwan, showing sympathy and support for the Taiwan authorities.

\section{Tibet Issues}

From 1987 to 2009, European Parliament had approved 33 resolutions on Tibet Issues, the main contents of which included supporting Tibet's independence or self-government, caring the democratic and human rights status of Tibet and supporting Dalai clique. Some of the resolutions required the delegates on behalf of Chinese government and Dalai started conversations. European Parliament also sent the invitation to Dalai Lama to visit EU Parliament. In these resolutions, Tibet issues were hooked with the Sino-European economic and trade relations as well as EU's arms sales to China and so on. On September 23, 2007, German Premier Angela 
Merkel conducted a "private meeting" with Dalai Lama in the Premier House. On December 7, 2008, former President of France Nicolas Sarkozy assuming the rotating presidency of the EU met Dalai Lama as the President of France and rotating President of the EU despite the repeated objections of China (SUN, 2008).

Chinese government has been opposing many resolutions of European Parliament regarding Taiwan and Tibet Issues as well as the behaviors of certain leaders of the member countries of EU regarding Dalai Lama. All of these behaviors were deemed by China as interference in China's internal affairs. For this reason, Chinese government expressed its discontent for many times. Sometimes, Chinese government had to take economic measures to warn EU about their improper behaviors.

\section{Disagreement Regarding Critical International Political Issues}

China and EU had sharp differences in how they approach the international political issues, including Iran nuclear issue, the war in Afghanistan, the war in Libya, Syria Crisis, and Ukraine Crisis. Highly waving the banner of "Human Rights above Sovereignty", EU handled the international issues with its own stands. China advocates respecting the state's sovereignty and adheres to the principle of "non-interference of internal affairs". All of these significant differences bring forth serious contradictions and conflicts in the political relations between China and Europe.

The political relations between China and EU are of cooperative nature as well as conflictive sense. Take a close view of the development of Sino-European relations for the past two decades, China and European countries have closer political relations themed with mutual exchanges and cooperation with fewer conflicts. Such an attitude was clearly demonstrated in one incident in February 1998. EU council of foreign ministers agreed to waive the policy against China in issue of human rights. At the Human Rights Meeting of UN, EU as a whole and many of its member countries did not present or support any resolutions that were against China's human right records (WANG, 2004). Since 2010, European Parliament approved fewer resolutions regarding the human rights to China, Taiwan issues and Tibet issues. China and EU have close cooperation in the economic, political and cultural fields and so on.

\section{Reasons for the Duality of Sino-European Political Relations}

Why are there cooperation and conflicts co-existing in Sino-European political relations? Why are the Sino-European political relations heading toward the direction, to which cooperation overrides contradiction. Some explain it from the perspectives of economic and trade relations as well as economic interests. They believe that after the occurrence of European Debt Crisis, EU made demands on China. As a result, the conflicts and frictions between China and EU became less frequent. To the researcher's knowledge, other than economic factors, cultural value is one critical factor that cannot be ignored.

Cultural value system is the value system identified by most people in the country or certain regions and carried down with continuity for a long time. Cultural values reveal the manner of thinking and criteria of right or wrong of a country and member countries, which represent the core of soft power of a country. Culture values play an instructive role in guiding the development of a country's ideology, political culture, national psychology and the foreign policies of the government, which exert tremendous impact on the decision making and behaviors of a country's leaders regarding foreign policies to a large degree.

EU is a union composed of many sovereign state members. It is difficult for such a Union to use military power and economic strength to fully play its role in the world, but it can use its soft power to make impact. 
Therefore, EU claims itself to be a "regulating force in Europe". The common cultural value system is the core of soft power owned by EU. It is also the driving force in a deeper sense to promote the European integration. EU attaches primary importance to disseminate thoughts and cultural values to the outside, aiming to influence the whole world with the cultural values and principles of EU.

China is a country with acute attention to the soft strength of culture. As economic development further speeds up, China shows more and more concerns over the construction of soft strength. In the international community, China spares no efforts to publicize the thoughts of harmony, peace, cooperation and mutual benefits. China is developing sound bilateral relations with many countries based on the "five principles of peaceful coexistence". As a result, cultural values have significant influence on the evolution of Sino-European political relations. This article offers an analysis of the causes for duality of cooperation and conflicts of Sino-European political relations from the perspective of cultural values.

China and Europe have great differences in history, culture, politics, economics and social systems. However, China and EU have similarities and differences in terms of cultural values, both of which determine the duality of Sino-European political relations to a large degree.

\section{Similarities of Cultural Values Between China and EU}

\section{Peace and Cooperation}

Peace and cooperation is the kind of cultural values that can unite all the member countries of EU. The value of peace derives from the memory and review of the disasters caused by the wars, in particular the two world wars, to Europe in modern history. Since the World War II, all the countries in Europe desperately need assurance of state security and avoidance of wars to restore and develop their economy quickly and improve people's life. Therefore, peace and cooperation become the common goal and interest of all the countries in Europe. They also become the common cultural values of European Community/European Union.

Chinese people always advocate the values of peace and cooperation. Over 2000 years ago, the thoughts of "harmony" emerged as a theoretical system, including the harmonious dialectics, value systems, and ideal purposes in philosophy. Harmony means the appropriateness and rationality in behaviors, in particular in line with the law and the truth. Harmonious dialectics stress that "harmony overrides conflict". Its most fundamental assumption comes from the complementary nature of the origin of the universe. Every being has two sides, each of which is part of the other. The complementary movement of each side brings froth new things. Harmonious value system does not deny the existence of conflicts, contradictions and flights. Instead, it highlights the fact that the essence of universe is harmony. Despite the fact that "conflicts are prevalent, they are just the bypath derived from the "main avenue"; the role of conflicts lies in reaching for harmony and creation of new beings" (QIN, 2011).

Harmonious thought and values have obvious reflection in China's foreign policy. In the 1950s, the Chinese government presented the "five principles of peaceful coexistence", namely "mutual respect for sovereignty and territorial integrity, non-aggression, non-interference in each other's internal affairs, equity and mutual benefits and peaceful coexistence". In the 1980s, DENG Xiao-ping put forward the diplomatic policy of "keeping a low-key profile, waiting for the right time to give one's capacity into full play". Since the 21 st century, Chinese government proposed the ideal purpose of "building the harmonious world", adopting the foreign policy of "establishing good relations with neighbors, ensuring security and prosperity", and "adhering to the new concept of security featured with mutual trust, mutual benefit, equity and cooperation" (ZHANG, 2009). 
In line with the principles and guidelines mentioned above, China actively sought to develop relations with EU. In the process, peace and cooperation among other cultural values play a positive role in promoting the Sino-EU relations.

\section{Cultural Diversity}

European countries have common origins of civilization, which constitute a kind of lasting and great force to promote the European integration. It also serves as the foundation to build up the soft strength of EU. However, due to that there are many member countries in EU, cultural diversity exists. As a union made up of sovereign nations, its duty is to respect the individual personality of each member country while disseminating the common features of the EU. Therefore, it has been one of EU's value systems to respect the cultural diversity. EU promotes cultural diversity not only inside the European Union, but also in the world as a whole.

France and EU actively stimulated the United Nations Educational, Scientific and Cultural Organization (UNESCO) to implement Convention on the Protection and Promotion of the Diversity of Cultural Expressions, which forms a typical demonstration for EU to advocate the cultural diversity. In November 2011, at the 31st conference of UNESCO, Universal Declaration on Cultural Diversity was approved. In August 2003, European Commission issued a communique entitled "vers un instrument international sur la diversitè". At the time being, 25 member countries of EU showed their unanimous consensus with regard to the issue. Such a fact further stimulated the issuance of Convention on the Protection and Promotion of the Diversity of Cultural Expressions.

In China, harmony in diversity has been advocated with a long history. We respect cultural diversity, seek common ground while putting aside differences, coexistence and mutual benefits. Harmonious thought of China, i.e. "harmony in diversity" has a lot in common with the cultural diversity concept in EU. Such similarity is reflected in their attitudes and behaviors in the international community. Both China and EU are opposed to hegemonism. They all identify themselves with a multi-polar world. Therefore, they can cooperate in various areas, including nuclear disarmament, nuclear non-proliferation, developing new energy and environmental protection. In the bilateral relations, China and EU continue to carry out the political dialogues and cultural exchanges and cooperation.

\section{Differences in Cultural Values Between China and EU}

\section{On Democracy, Rule of Law, Human Rights and Freedom}

Though both China and EU acknowledge the cultural values of democracy, rule of law, human rights and freedom, both parties have sharply different understandings of the meaning and realization forms regarding the cultural values.

With regard to how to realize democracy, EU and nearly all the European people believe in multi-party parliamentary democracy. Chinese government, on the other hand, believes that there are many ways to help realize democracy. The multi-party parliament democracy popular in Western countries is just one form. The system of People's Congress and the multi-party cooperation mechanism under the leadership of Chinese Communist Party is another form of realizing democracy.

When it comes to the realization form of rule of law, EU believes that separation of powers, judicial independence are important forms of rule of law. However, Chinese government does not imitate the western means. Instead, China insists to implement the power separation and judicial system under the leadership of 
Chinese Communist Party.

As for human rights and freedom, EU holds to the view that human rights refer to the individual human rights under the protection of the constitution and laws. Freedom refers to the individual freedom, i.e. the freedom in the legal framework. However, the core value system of China is holistic. Such opinions are advocated including "obligations override rights; responsibilities precede freedom; and the group is more important than individuals". Chinese government believes that human rights refer to not only the individual human rights, but also the collective human rights. Human rights first are the people's right to exist, i.e. life security as the fundamental right for people to have.

EU has the superiority in terms of culture and morality, believing that "they should be the formulator of the international system standards, through which they can influence the whole world". EU has deep prejudice against China's ideology and political system. They believe that China is under the "autocratic rule in the transitional period". Therefore, "for China, the constructive contact with China by EU has a clarified purpose of changing China so that China can meet the international standards" (PAN, 2011; DING, 2009). During the communication with China, EU always attempts to export their standards regarding human rights, rule of law, and democracy so that China can change to be more like the Western countries. European parliament approved many resolutions regarding human rights in China, Taiwan issues and Tibet issues, claiming that Chinese government violates human rights, and interferes with the freedom of citizens. The leaders of EU and its member countries meeting with Dalai Lama, including Germany, France, and UK fully illustrate the point. All of these behaviors by EU are against China. China and EU often have contradictions and conflicts regarding these issues.

\section{Relations Between Human Rights and State Sovereignty}

That sovereignty weighs over human rights (Is it the reverse?) is quite popular in Western countries, which derives people's awareness of the loftiness of human rights. With regard to the issues such as Libya crisis, Syrian Crisis, the War in Afghanistan among others, EU adheres to the principle that "human rights weigh over sovereignty". EU shares the same position with USA, by adopting the force to interfere or supporting the rebels. Chinese government, however, has very different opinions. It opposes to the idea of "human rights weigh over sovereignty". The principle of respecting national sovereignty and non-interference is advocated in China. It follows that China and EU have different opinions regarding the issues like Libya crisis, Syrian Crisis, the War in Afghanistan and so on.

In a word, the common ground of China and EU's cultural value systems has positive impact regarding the Sino-European political relations. The differences of cultural values exert negative impact on the political relations between China and EU. Both share the common ground, suggesting that they would not turn against each other as enemies. The differences of cultural values between them imply that China and the EU member countries cannot develop partnerships as those achieved in security community. Therefore, the Sino-European relations are of cooperation and competition, lying in between a friend and a rival.

As both China and EU adheres to the principle of peace and cooperation, the political dialogues and cultural communications are continuing. The bilateral trade relations develop at a faster pace. Both China and EU have intensely high complementary relations. Therefore, the understanding between China and EU becomes more and more profound. Although China and EU have conflicts and frictions, taking a long run view, we have good reasons to believe that the political relations between China and the member countries of EU will 
head for a brighter future.

\section{References}

DING, Y. F. (2009). Different expectations causing discord in China-Europe relations. Chinese Journal of European Studies, 5 , 68-76.

LI, J. K. (2014, June 10). China-EU comprehensive strategic partnership: Peaceful development and mutual benefit and win-win. Legal Daily.

PAN, C. X. (2011). Problematizing “constructive engagement” in EU China policy. In R. Vogted (Ed.), Europe and China: New issues and changing global roles (pp. 37-57). Hong Kong: Hong Kong University Press.

QIN, Y. Q. (2011). Chinese culture and its influence on the foreign policies of China. Studies of International Issues, 5, 21-33.

SUN, L. Z. (2008, December 12). Nicolas Sarkozy seeing Dalai Lama: An irrational behavior. Elite Reference.

WANG, L. (2004, April 29). Landmark events in the development of Sino-EU relationship. China Network.

ZHANG, S. (2009, September 24). Elaboration on new security concept of China by President HU Jin-tao at the UN Forum. China News Network. 